\title{
Effect of Social Networking Sites on Students' Engagement and Motivation in Computer Science in Bayelsa State, Nigeria
}

\author{
Marie Ebifagha Zakana (M.Ed) \\ Dr. Esther Fomsi F. (PhD) \\ Curriculum Studies and Educational Technology, Faculty of Education, \\ University of Port Harcourt, Nigeria
}

\begin{abstract}
The use of Social Networking Sites (SNS) in the classroom is not a new phenomenon in educational research. Several researchers have investigated the use of SNS and its effect on students. This study investigated the use of Edmodo and Facebook as SNS for engaging senior secondary Computer Science students in Bayelsa State, Nigeria. The study adopted quasi experimental design. Eighty (80) S.S.II Computer Science students were purposively sampled and used for the study. Two research questions were answered, and two hypotheses tested at 0.05 level of significance. The Instruments used for data collection were titled "Computer Science Achievement Test" (CSAT) and "Students' Engagement and Motivation toward Facebook and Edmodo Questionnaire" (SEMFEQ). CSAT pre-test and post-test was made up of 40 multiple choice questions while SEMFEQ was made up of two parts (A and B) and part B was made up of two sections (A and B of 25 items each). Data collected were analyzed using mean and standard deviation to answer research questions and independent t-test was used for the hypotheses. Cronbach Alpha was used to compute the internal consistency of SEMFEQ and a reliability coefficient of 0.88 was obtained. The findings revealed of the two dependent variables in this study; engagement and motivation that the first independent variable, Facebook had a higher significant effect on senior secondary Computer Science students than Edmodo, the second independent variable. Recommendations made based on the findings amongst others include incorporating these platforms to support classroom instruction.
\end{abstract}

Keywords: Edmodo, Facebook, Engagement, Motivation, Computer Science 


\section{Introduction}

Learning environment in the 21 st century has extended beyond the walls of the traditional classroom setting as a result of technology permeating almost every sector in the society, especially the education sector. With the innovation of web 2.0 tools, the quality of teaching and learning is enhanced when used to deliver instruction and it also encourages student-centred learning. The instructional use of technology makes this possible as it develops students' interest, motivation and proficiency. Students' attention is drawn to the appealing learning environment which engages and motivates them in the process of learning. Engagement and motivation of students are essential factors that propel students to succeed in learning activities. Teachers' major concern is to motivate students and engage them in the learning process so that learning becomes exciting and meaningful instead of a burden. Technology alone cannot contribute to learning but helps to expedite learning by providing a rich environment when incorporated into learning activities.

Edmodo is an effective web 2.0 tool designed and developed by Jeff O'Hara and Nick Borg in 2008 for teachers, students, school administrators and parents. It is a free, private and secure educational social networking site available at www.Edmodo.com. The goal of Edmodo is to support educators explore social media and easy customization of the classroom. Edmodo has administrative and organizational functionality which actually reflects the natural rhythms and cultures of school classrooms (Wallace, 2014). Teachers can use Edmodo to form communities of practice for themselves and their students. While most formal training can be done in classes or in isolation, social learning systems may offer the ability to develop learning communities in which groups of learners and trainers share information and collaborate on their learning experience (Admin, 2015).

Facebook was designed by Mark Zukerberg at Harvard University in 2004 and it is the most visited and leading social networking platform that has caught the attention of most teeming youths. Since it captivates students' interest, educators seize its potential in engaging students for academic work by adopting it into the classroom. Just like Edmodo, the platform fosters interactivity, collaboration and participation. Unlike Edmodo, however, Facebook does not have certain security features. It allows friends and peers to peek into the profiles of their friends and make comments on their pages.

Computer Science/Studies is a subject taught in primary, secondary and technical schools in Nigeria. The purpose of computer technology education is to empower students acquire basic scientific knowledge, to be creative, confident and better thinkers which can help them in higher level of education and in life. Learning Computer Science does not just expose learners to acquire theoretical knowledge but also practical skills (hands-on 
experience) that can make them useful, productive and achieve success when found in their different fields of expertise in the workplace.

\section{Literature Review}

The main focus of Edmodo network is about teaching and learning amongst students and teachers (Charoenwetand Christensen 2016). Through Edmodo interface, teachers send notes, assignments, quizzes, etc, to students while students respond by posting comments, events, alerts, etc, to the teacher. Buescher (2010) postulates that Edmodo is an easy way to integrate technology into students' assessment. Al-Okaily (2013) found that the use of Edmodo via mobile devices could prompt students to collaborate in an intensive English programme. Likewise, Enriquez (2014) stated that the collaboration provided by Edmodo enabled students to improve their online work quality. Balasubramanian, Jaykumar and Fukey (2014) see Edmodo as a wonderful and user-friendly social networking platform that enables students to enjoy working in an online class, and also inspires teachers to reappraise the way they conduct their classes. Hart (2015) said in a recent survey, Edmodo was ranked one of the best learning tools by professionals all over the world. It is being used on daily basis by more than fifty million teachers and students around the world ("Edmodo Website" 2015). Habley (2011) revealed that the American Association of Librarians in 2011 recognized Edmodo as one of the top 25 websites that fosters the qualities of innovation, active participation and collaboration in the category entitled "Social Networking and Communication". This implies that the incorporation of Edmodo as a learning platform for Computer Science can promote motivation, engagement, interactivity, collaboration amongst learners' and also quality of learning.

Social networking could become an integral component of the educational environment if implemented effectively. With the aid of social networking, learning is facilitated outside classrooms. Edmodo, a free, safe and private educational social networking platform developed by Nick Borg and Jeff O' Hara in 2008 for educators, students and parents. Edmodo is a portal that presents information in an engaging and motivating way that becomes a controlled environment suitable for peer tutoring (Mokhtar and Dzarkiria 2015). In March 2014, research shows that over 1.28 billion users interacted, shared files and communicated in groups by using Facebook services (Shroeder and Greenbowe, 2009). They further posit that Facebook groups are considered educational tools that benefit interaction, learning, learning motivation, and class climate. Students develop critical thinking in the process of interaction which may help them to excel in their academic performance. Shroeder and Greenbowe (2009) reported that people in Facebook groups address complex topics and provide detailed replies, and that 
discussions in Facebook promote high-level thinking skills. Chen (n.d.) also reported that using Facebook groups positively, influenced student motivation, affective learning, and the classroom climate. Downes (2007) argues that Facebook is distinctive from other social networking sites because it has stronger roots in the academic community. He further proposed that the site's varied and distinctive functions allow it to provide a very different model of how online tools can be used in educational contexts.

Student engagement refers to the degree of attention, curiosity, interest, optimism and passion that students show when they are learning or being taught, which extends to the level of motivation they have to learn and progress in their education ("Student Engagement" 2016). Martin and Torres (2016) defined Student engagement as meaningful student involvement throughout the learning environment. This indicates that students who engage in learning surpass those who do not and are not likely to drop out of school. Therefore, factors such as teacher, school, student, family, community, curriculum and resources influence student engagement. Student engagement also has an impact on their academic achievement and behaviour. Briggs (2015) affirmed that Student engagement is about increasing achievement, positive behaviour and a sense of academic belonging. It can also be measured in three dimensions as behavioural, emotional and cognitive.

This research is related to Connectivism learning theory. Connectivism learning theory is propounded by Stephen Downes and Geroge Siemen and it is described as the theory for the digital age. According to Downes (2007), connectivism is defined as the thesis that knowledge is distributed across a network of connections, and therefore that learning consists of the ability to construct and traverse those networks. Connectivism is the integration of principles explored by chaos, network complexity and self-organisation theories (Siemen 2004). Connectivism is a learning theory which is centred on networks. The theory posits that learning takes place as a result of formation of connections within networks and sees learning through the connection of network with nodes. Learning used to be competitive, coercive and personal in the past, but today it is collaborative, interactive and participatory. The society in which we find ourselves today is networked socially and individuals search for information from technological systems that have structured learning. Technology such as social networking platforms like Facebook, Edmodo, etc make these connections possible. This implies that the application of these networks will heighten students' engagement and learning motivation as it relates to this study. According to Kongchan (2012), online social networks are an excellent tool for knowledge construction based on social relations, conversation, collaboration and shared work. This theory is related to the present study which compares two social networking platforms, Edmodo and Facebook on students' levels of engagement and 
motivation because learning is effective with technology and networks. This is helpful in arousing students' motivation and engagement in the course of learning, increasing their network skills thereby making them lifelong learners as they continue to use it in the workplace.

Sanders (2012) conducted a study on an examination of the academic networking site Edmodo on students' engagement and responsible learning. The researcher used 42 high school Chemistry students from South Carolina, USA as the sample size. A survey questionnaire with a 4-point Likert scale was used as instrument for data collection. Descriptive statistics was used to analyze the collected data. Findings revealed that integrating Edmodo platform stimulates student engagement and responsible learning. Also, Staines and Lauchs (2013) investigated students' engagement with Facebook in a university undergraduate policing unit in Brisbane, Australia. A sample of 79 undergraduate students was used in this study and a survey questionnaire to draw data from the students. Findings indicated that Facebook had increased their aptitude to engage with and critically analyze the unit content.

Alshawi and Alhomoud (2016) conducted a study on the impact of using Edmodo on Saudi university EFL students' motivation and teacherstudent communication. The researcher employed random sampling to select 255 university students as the sample size is a survey questionnaire with 4point Likert scale, close-ended items and internal consistency ranged from 0.81 to 0.91 using Cronbach Alpha Reliability Coefficient Method. The research questions were answered using mean and t-test. Findings indicated that Edmodo had a positive impact on students' motivation in their language learning process. Also, Lam (2012) conducted a study on an innovative research on the usage of Facebook in higher education context of Hong Kong. The researcher employed convenient sampling to select 312 university students as the sample size and a survey questionnaire with 7-point Likert scale and internal consistency of .72 using Cronbach Alpha Reliability Coefficient Method. Findings revealed that participation and communication amongst other variables influence significantly on student learning motivation.

\section{Statement of the Problem}

Logic gates are a difficult concept for many Computer Science students in Nigeria. The authors have observed that whenever the concept is introduced in class, students switch off mentally and get distracted with other activities, such as secretly using their mobile phones in class without being caught by the teacher. It is with respect to this problem that the authors decided to use a different approach to handle the topic: Logic gates. Will the use of Edmodo and Facebook in teaching Logic gates improve students' engagement and motivate them to learn? This is the problem that this research seeks to 
address.

\section{Aim and Objectives of the Study}

The aim of this study is to compare the instructional use of Edmodo and Facebook and their effects on students' engagement and motivation. In specific terms, the study intends to:

1. Ascertain the level of students' engagement when using Edmodo and Facebook.

2. Determine the extent to which the motivation level of students instructed with Edmodo differ from those instructed with Facebook.

\section{Research Questions}

1. How does the level of engagement of students using Edmodo differ from those using Facebook?

2. To what extent does the motivation level of students instructed with Edmodo differ from those instructed with Facebook

\section{Hypotheses}

The following null hypotheses were formulated and tested at 0.05 level of significance.

1. There is no significant difference between Edmodo and Facebook on the level of students engagement in Computer Science.

2. There is no significant difference between Edmodo and Facebook on the level of students motivation in Computer Science.

\section{Methods}

Quasi experimental design was the research design used in this study. The population of this study comprised all Computer Science students in the three unity schools in Bayelsa State. Bayelsa State is one of the states in the Niger Delta region of Nigeria. Its capital is Yenagoa and is known for having one of the largest crude oil and natural gas deposits in Nigeria. The estimated population of people in Bayelsa State according to Olukoya (2016), National Population Commission and National Bureau of Statistics 2016 census data is about 2,277,961 which is ranked as the 35th most populous state in the country.

A sample of 80 senior secondary school two (S.S.II) Computer Science students was drawn from two unity schools in Bayelsa State. Purposive sampling technique was used for this study to select the schools. The instrument for data collection is Student Engagement and Motivation with Facebook and Edmodo Questionnaire (SEMFEQ). The face and content validity of the instrument were done by three experts in Educational Technology, Measurement and Evaluation and Computer Science 
Department. A reliability of 0.88 was established for SEMFEQ using Cronbach Alpha coefficient. Facebook motivation sub scale questionnaire had a reliability coefficient of 0.74 , Facebook engagement sub scale had 0.88 . Edmodo motivation and engagement sub scale had reliability coefficient of 0.68 and 0.70 respectively.

As regards the procedure, two technology lesson plans for both experimental and control groups were prepared for subject teachers to use. Computer Science teachers were trained on the instructional use of Edmodo and Facebook for one week. Thereafter, subject teachers trained the students the following week on the same platforms. For the experimental group, the subject teacher connected to the internet and signed up for online classroom via http://www.edmodo.com. Students were grouped into five, each of eight members and the teacher introduced Edmodo to them as they were shown Edmodo application. Students were asked to create account in Edmodo through the guidance of the teacher. The teacher then explained the function and interface of the different components in the platform. After introducing students to the different tools and their functions, they later explored the learning platform with the assistance of the teacher. Power point slides of lesson notes were used to guide students and enabled them to collaborate on a given class work which they posted to the subject teacher for assessment.

For the control group, the subject teacher connected to the internet and signed up for online classroom via http://www.facebook.com. Students were grouped into five, each of eight members and the teacher introduced Facebook secret group, though many of them are familiar with Facebook and also have Facebook accounts. The teacher creates a class on Facebook secret group as the administrator and registered students as well. This "secret group" was meant solely for the teacher and registered students to join, post, view, like, comment and share. Power point slides of lesson plan were used to guide students and enabled them to collaborate on a given classwork which they posted to the subject teacher for assessment. The instruments, Computer Science Achievement Test (CSAT) pre-test and post-test of 40 multiple choice questions were administered to students at the beginning and end of the lesson respectively while SEMFEQ was administered to students at the end of the lessons. The research questions were answered using mean and standard deviation, while t-test was used to test the hypotheses at 0.05 significant level.

\section{Results and Discussion}

Research Question 1: How does the level of engagement of students using Edmodo differ from those using Facebook? 
Table 1: Mean \& standard deviation analysis of the difference in the level of engagement for students instructed with Edmodo and those instructed with Facebook

\begin{tabular}{lllll}
\hline Engagement & $\mathrm{N}$ & Mean & Std. D & Std. Error \\
\hline Edmodo & 40 & 63.400 & 15.348 & 2.4268 \\
Facebook & 40 & 79.900 & 6.9089 & 1.0924 \\
\hline
\end{tabular}

Table 1 shows that the engagement level of the Facebook group with mean score of 79.900 is higher than that of the Edmodo group with mean score of 63.400 .

Hypothesis 1: There is no significant difference between Edmodo and Facebook on the level of students engagement in Computer Science.

Table 2: $\quad$ Independent samples t-test analysis of significant difference in the level of engagement for students instructed using Edmodo and those instructed using Facebook

\begin{tabular}{|c|c|c|c|c|c|c|c|c|c|}
\hline Engagement & $\mathbf{N}$ & $\bar{x}$ & SD & Df & $\mathbf{T}$ & Sig. & $\mathbf{P}$ & Decision & \\
\hline Edmodo & 40 & 63.40 & 15.34 & & & & & Reject & $\mathrm{Ho}_{1}$ \\
\hline Facebook & 40 & 79.90 & 6.90 & 78 & -6.200 & 0.000 & 0.05 & $\mathrm{P}<0.05$ & \\
\hline
\end{tabular}

Table 2 reveals that the null hypothesis of no significant difference is rejected. Thus there is a significant difference in the engagement level of students taught with Edmodo and those taught with Facebook.

The result obtained from research question 1 as reflected in table 1 shows a mean score of 63.400 for students instructed with Edmodo and a mean score of 79.900 for students instructed with Facebook. This implies that instructional use of Facebook has more impact on students' engagement level in the topic Logic gates than those taught with Edmodo. When the data was subjected to statistical analysis as shown in table 2, the computed $t$ value at 78 degree of freedom was $-6.200, p=.000$ which is less than the significant level of 0.05 and so the null hypothesis of no significant difference in the level of engagement for students instructed with Edmodo and those instructed with Facebook was rejected. This indicates that the level of engagement of students instructed with Facebook and those instructed with Edmodo is significantly different and in favour of Facebook. The finding means that those instructed with Facebook has a higher level of engagement than those instructed with Edmodo. This result is not surprising as learners' attention was drawn to the appealing technology-driven student-centred learning environment of both platforms which engaged them while learning. The higher result of those instructed with Facebook could be attributed to using a more familiar and comfortable SNS than a less familiar and comfortable ESNS for academic work. To support this, some past researchers like Staines and Lauchs (2013) in a study on students' engagement with Facebook in a university undergraduate policing unit in Brisbane, Australia, found out that Facebook had increased their aptitude to engage with and critically analyze the unit 
content. Also, the finding for Edmodo is in line with those of Sanders (2012) in a study on an examination of the academic networking site Edmodo on students' engagement and responsible learning found out that integrating Edmodo platform stimulates student engagement and responsible learning.

Research Question 2: To what extent does the motivation for learning Computer Science differ for students instructed with Edmodo and those instructed with Facebook?

Table 3: Mean \& standard deviation analysis of the extent motivation for learning

Computer Science differ for students instructed with Edmodo and those instructed with Facebook

\begin{tabular}{lllll}
\hline Motivation & $\mathrm{N}$ & Mean & Std. D & Std. Error \\
\hline Edmodo & 40 & 69.750 & 11.610 & 1.8358 \\
Facebook & 40 & 81.850 & 6.6353 & 1.0491 \\
\hline
\end{tabular}

Table 3 shows that the Facebook group with a mean score of 81.85 had a higher motivation level than the Edmodo group which had a mean score of 69.75 .

Hypothesis 2: There is no significant difference between Edmodo and Facebook on the level of students motivation in Computer Science.

Table 4: $\quad$ Independent samples t-test analysis of significant difference in the motivation for learning Computer Science for students instructed using Edmodo and those instructed using Facebook

\begin{tabular}{llllllllll}
\hline Motivation & $\mathbf{N}$ & $\overline{\boldsymbol{X}}$ & SD & Df & T & Sig. & P & \multicolumn{2}{l}{ Decision } \\
\hline Edmodo & 40 & 69.75 & 11.6 & \multirow{2}{*}{78} & -5.723 & 0.000 & 0.05 & $\begin{array}{l}\text { Reject } \\
\text { P }<0.05\end{array}$ & $\mathrm{Ho}_{1}$ \\
Facebook & 40 & 81.85 & 6.63 & & & & & \\
\hline \multicolumn{7}{c}{$\mathrm{t}(78)=-5.723 \mathrm{p}<0.5$, i.e. $\mathrm{p}=.000$ is less than 0.05.} & &
\end{tabular}

Table 4 shows that the null hypothesis of no significant difference is not accepted. Thus the motivation level of students taught with Edmodo and those taught with Facebook differ significantly.

The data presentation in table 3 provided answer to research question 2. Findings showed that the extent of motivation for learning with Facebook is higher with a mean score of 81.850 as against the mean score of 69.750 for learning with Edmodo. When subjected to statistical analysis as shown in table 4 , the $t$ value at 78 degree of freedom is $-5.723, p<0.5$, i.e. $p=.000$ is less than 0.05 . Therefore the null hypothesis of no significant difference in the motivation level for learning Logic gates with Facebook and Edmodo is not accepted. This indicates that the motivation level of students instructed with Facebook differs significantly from those taught with Edmodo. The finding is expected as Facebook is the most popular and most widely used SNS. Conversely, the authors are surprised with the results since Edmodo is designed for school and Facebook for social purpose. Again, Edmodo was 
just introduced to students for the first time, unlike Facebook which has been in use for many users. To buttress this, Lam (2012) in a study on an innovative research on the usage of Facebook in higher education context of Hong Kong found out that participation and communication amongst other variables influence significantly on student learning motivation. For Edmodo, other past researchers like Alshawi and Alhomoud (2016) in a study on the impact of using Edmodo on Saudi university EFL students' motivation and teacherstudent communication found out that Edmodo had a positive impact on students' motivation in their language learning process.

\section{Conclusion}

The use of Facebook had a higher positive effect than Edmodo on level of engagement of students. This is attributed to the fact that learners' attention was drawn to the appealing technology-driven student-centred learning environment. The level of engagement of students instructed with Edmodo is also high but lesser than that of students instructed with Facebook. Students instructed with Facebook differ significantly from those instructed with Edmodo as regards motivation level of students for learning in favour of those instructed with Facebook. This is attributed to the fact that Facebook platform is most widely used which has become a part of the lives of many youths. The level of motivation for students instructed with Edmodo is high, though lesser than those instructed with Facebook which showed that Edmodo platform, though not familiar, also motivated them in the process of learning. At first, students found it challenging using the Edmodo platform since they had not used it before. The educational evidence shows that Edmodo and Facebook are supportive learning tools that could promote students' engagement and motivation.

\section{Recommendations}

Based on the findings, discussion and conclusion, the following recommendations were made:

(i) Facebook and Edmodo should be integrated by educators as supportive learning tools into classroom instruction to help build a community of learners.

(ii) Teachers should be trained on the academic usage of social networking platforms like Facebook and Edmodo for classroom instruction to improve students' engagement and motivation.

\section{References:}

1. About Student Engagement. Retrieved fromhttp://www.education.vic.gov.au/school/teachers/studentmanage ment/Pages/about.aspx 
2. Admin, B. (2015). Six reasons to include Social Learning in your Lesson Plans. Accessed September 8, 2016. https://bloomfire.com/blog/six-reasons-to-include-social-learning-inyour-training-plans/

3. Al-Okaily, R. (2013)."Mobile learning and BYOD: implementations in an intensive English program."Learning and Teaching in Higher Education: Gulf Perspectives 10, no 2(2013): 141. Retrieved fromhttp://citeseerx.ist.psu.edu/viewdoc/download?doi=10.1.1.820.6 $859 \&$ rep $=$ rep $1 \&$ type $=$ pdf

4. Alshawi, S.T. \& Alhomoud, F.A. (2016). The Impact of using Edmodo on Saudi University EFL Students' Motivation and TeacherStudent Communication. International Journal of Education, 8(4), 105-118. Retrieved May 25, 2017 from http://dx.doi.org/10.5296/ije.v8i4.10501

5. Balasubramanian, K., Jaykumar, V.\&Fukey, L.N. (2014). "A study on Students Preference towards the use of Edmodo as a Learning Platform to create responsible Learning Environment". Paper presented at the $5^{\text {th }}$ Asia Euro ConferenceProcedia - Social and Behavioral Sciences144(2014):416-422. http://www.sciencedirect.com

6. Bayelsa State - Wikipedia.Retrieved from https://en.wikipedia.org/wiki/Bayelsa_State

7. Briggs, S. (2015). Here's What Learners have to say about student engagement.

Retrieved fromhttp://www.opencolleges.edu.au/informed/features/heres-whatlearners-have-to-say-about-student-engagement/

8. Buescher, E. (2010). Edmodo: A white paper.Retrieved from http://coe.winthrop.edu/jonesmg/LTI/2010Fwhitepapers/Eileen_Bues cher.pdf

9. Charoenwet, S.\& Christensen, A. (2016). "The Effect of Edmodo Learning Network on Students' Perception, Self-regulated Learning Behaviors and Learning Performance."Paper presented at The 10th International Multi-Conference on Society, Cybernetics and Informatics. Retrieved from www.iiis.org/CDs2016/CD2016/Summer/papers/EA948HG.pdf

10. Chen, Y. (2014). "Effect of using Facebook Group as a Learning Management System."Computers in Education Journal 5 (4): 42 53. Retrieved fromhttp://www.asee.org/papers-andpublications/publications/division-publications/computers-ineducationjournal/The_Effect_of_Using_a_Facebook_Group_as_a_Learning_M anagement_System.pdf 
11. Connectivism.

Retrieved

fromhttp://education2020.wikispaces.com/connectivism

12. Downes, S. (2007). What Connectivismis?Retrieved fromhttp://halfanhour.blogspot.com/2007/02/what-connectivismis.html

13. Edmodo

Instruction

Manual.

Retrieved fromhttp://www.pdst.ie/sites/default/files/Edmodo\%20Instructions_0. pdf

14. Edmodo Overview. Edmodo Tutorial. Retrieved from http://etec533edmodo.weebly.com/overviewrationale.html

15. Edmodo Website (2015). Retrieved fromwww.Edmodo.com

16. Engagement Concept. Retrieved from http://www.isbe.net/learningsupports/pdfs/engagement-concept.pdf.

17. Enriquez, M.A. S. (2014). "Students' Perceptions on the Effectiveness of the Use of Edmodo as a Supplementary Tool for Learning."A paper presented at DLSU(De La Salle University) Research Congress, Manila, Philippines, March 6-8, 2014.Accessed September 12, 2016. http://www.dlsu.edu.ph/conferences/dlsu_research_congress/2014/_p df/proceedings/LLI-II-010-FT.pdf

18. Everything you need to know about Facebook Groups.(2013). Retrieved fromhttps://mashable.comhttps://mashable.com/2013/01/28/facebook -groups-101/\#T.mplnyuWgqN

19. Habley, J. (2011).AASL announces 2011 Best Websites for Teaching and Learning.

Retrieved

fromhttp://americanlibrariesmagazine.or/news.ala/aaslannounces2011-best-websites-teaching-and-learning

20. Hart, J. (2015). Top 100 Tools for Learning 2013 In Centre for Learning \& Performance Technologies. Accessed on September 12, 2016.http://c4lpt.co.uk/top100tools/

21. Kongchan, C. (2012). "How a non-digital-native teacher makes use of Edmodo."Proceedings from the International Conference "ICT for Language Learning" $5^{\text {th }}$ Edition, Florence, Italy. Retrieved fromhttp://conference.pixel-

online.net/ICT4LL2012/common/download/Paper_pdf/90-IBT-18FP-Kongchan-ICT2012.pdf

22. Kongchan, C. (2013). "How Edmodo and Google Docs can change Traditional Classrooms."Proceedings fromthe European Conference on Language Learning, Brighton, UK.http://docplayer.net/10565983How-edmodo-and-google-docs-can-change-traditional-classroomschada-kongchan-king-mongkut-s-university-of-technology-thonburithailand.html 
23. Lam, L. (2012). An Innovative Research on the usage of Facebook in the Higher Education context of Hong Kong. Electronic Journal of eLearning, 10(4) 378-386. Retrieved February 9, 2018 from https://eric.ed.gov/?id=EJ986646

24. Martin, J.\&Torres, A. (2016). What is Student Engagement and why is it important?Retrieved fromhttps://www.nais.org/Articles/Documents/Member/2016\%20HS SSE\%20Chapter-1.pdf

25. Mokhtar, F. A., \&Dzakiria, H. (2015). "Illuminating the Potential of Edmodo as an Interactive Virtual Learning Platform for English Language Learning and Teaching."Malaysian Journal of Distance Education 17(1): 83-98. Retrieved from mjde.usm.my/vol 17_1_2015_Art.6(83-98).pdf

26. Ngwu, O.G.(2008). Relevance of Computer Studies in School Curriculum.Paper presented at the Nigerian Academic Forum, 14(1): 133-136. Retrieved from http://www.globalacademicgroup.com/journals/the\%20nigerian\%20a cademic\%20forum/Obiageli67.pdf

27. Nwankwo, C.O. (2013). Research Writing for Students of Research Enterprise (Rev. 5th ed.). Port Harcourt: Pam Unique Publishers.

28. Olukoya, S. (2016). Nigeria's Population Now 193.3 Million - NBS Estimates.Retrieved from http://investorsking.com/nigeriaspopulation-now-193-3-million-nbs-estimates/

29. Otuka, J.O.E., Akande, A.F. \&Iginla, S.L. (2012).New Computer Studies for Senior Secondary Schools 2. Lagos: LearnAfrica.

30. Sanders, K.S. (2012).“An Examination of the Academic Networking Site Edmodo on Students' Engagement and Responsible Learning."Ph.D. Thesis, University of South Carolina.

31. Sharma, V. (2016). Importance of Computer Education in Schools for Students.

fromhttp://www.klientsolutech.com/importance-of-computereducation-in-schools-for-students/

32. Siemens, G. (2004). A learning theory for the digital age. Retrieved fromhttp://www.elearnspace.org/articles/connectivism.htm

33. Schroeder, J. \&Thomas, J. G.(2009). "The Chemistry of Facebook: using Social Networking to create an Online Community for the Organic Chemistry Laboratory." Journal of Online Education,5(4).Retrieved from http://www.comminit.com/node/321375

34. Staines, Z. \& Mark, L.(2013). 'Students' Engagement with Facebook in a University Undergraduate Policing Unit." Australasian Journal 
of Educational Technology, 29(6): 792-804.Retrieved from https://ajet.org.au/index.php/AJET/article/view/270

35. Student Engagement.(2016).Retrieved from http://www.edglossary.org/student-engagement

36. Trowler, V. (2010). Student Engagement Literature Review. The Higher Education Academy. Retrieved from https://www.heacademy.ac.uk/system/files/studentengagementliteratu rereview_1.pdf

37. Wallace, A. (2014). "Social Learning Platforms and Flipped Classroom."International Journal of Information and Education Technology 4(4):293-296. Retrieved from www.ijet.org/papers/416T0001.pdf 